\title{
Correlation Between Irregular Qiraat And Arabic Linguistics In The Quranic Tafseer Book By Al-Razi
}

Mohamed Fathy Mohamed Abdelgelil, Hasan. A. F., Yusoh. F, El khayat. M. H. M., Razali. M. A., Ismail. F. Z., Ab Rashid, R

To Link this Article: http://dx.doi.org/10.6007/IJARBSS/v11-i7/10667

DOI:10.6007/IJARBSS/v11-i7/10667

Received: 24 May 2021, Revised: 26 June 2021, Accepted: 11 July 2021

Published Online: 30 July 2021

In-Text Citation: (Abdelgelil et al., 2021)

To Cite this Article: Abdelgelil, M. F. M., Hasan, A. F., Yusoh, F, El khayat, M. H. M., Razali, M. A., Ismail, F. Z., \& Ab Rashid, R. (2021). Correlation Between Irregular Qiraat And Arabic Linguistics In The Quranic Tafseer Book By Al-Razi. International Journal of Academic Research in Business and Social Sciences, 11(7), 16321639.

Copyright: (c) 2021 The Author(s)

Published by Human Resource Management Academic Research Society (www.hrmars.com)

This article is published under the Creative Commons Attribution (CC BY 4.0) license. Anyone may reproduce, distribute, translate and create derivative works of this article (for both commercial and non-commercial purposes), subject to full attribution to the original publication and authors. The full terms of this license may be seen at: http://creativecommons.org/licences/by/4.0/legalcode

Vol. 11, No. 7, 2021, Pg. 1632 - 1639

Full Terms \& Conditions of access and use can be found at http://hrmars.com/index.php/pages/detail/publication-ethics 


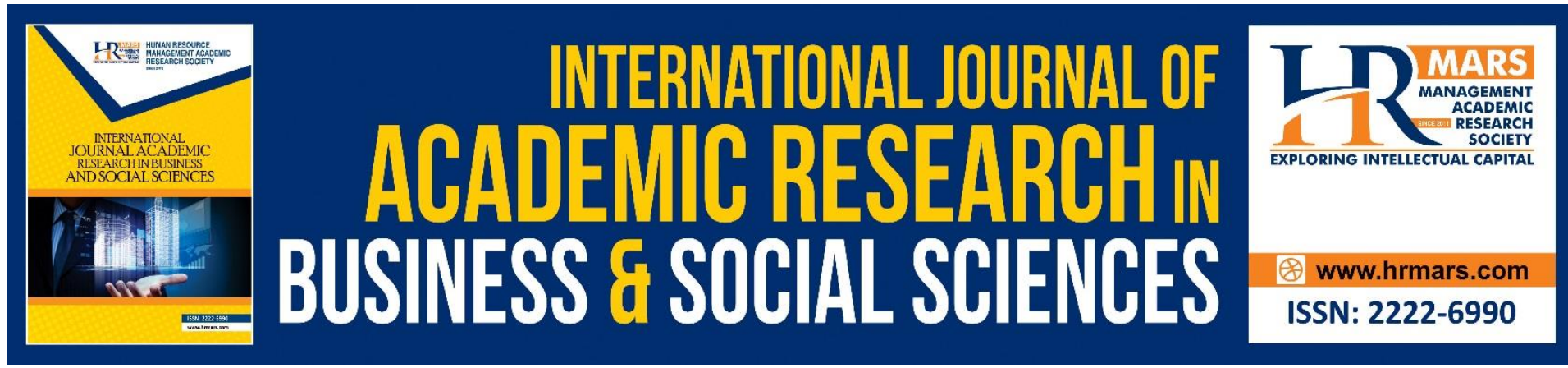

\title{
Correlation Between Irregular Qiraat And Arabic Linguistics In The Quranic Tafseer Book By Al- Razi
}

\author{
Mohamed Fathy Mohamed Abdelgelil \\ Faculty of Islamic Contemporary Studies (FKI), Sultan Zainal Abidin University (UniSZA), \\ 21300, Terengganu, Malaysia. \\ Emial: mfathy@unisza.edu.my
}
Hasan. A. F., Yusoh. F, El khayat. M. H. M., Razali. M. A., Ismail. F. Z., Ab Rashid, $R$

Faculty of Islamic Contemporary Studies (FKI), Sultan Zainal Abidin University (UniSZA), 21300, Terengganu, Malaysia.

\begin{abstract}
Many irregular Qiraat used to be accepted in terms of attribution and content but they become irregular following the standardization of rules of accurate Qiraah. While some may believe that we need to abandon irregular Qiraat altogether Like Imam Razi and Imam Ibn alArabi (i.e. not to recognize them as reliable sources for syntactic standardization). This purpose of this paper Actually the paper Reviews Correlation Between Irregular Qiraat and Arabic Linguistics In The Quranic Tafseer Book By Al-Razi By providing some example to show the extent to which irregular Qirraht can be uses an authoritative source in Arabic grammar on the one hand and the impact of irregular Qiraat on those grammatical rules. It also seeks to identify the relationship between Arabic phonetics and the other branches of Arabic linguistics. The researcher adopted an analytical approach by means of which We examined the Qur'anic Tafsser book by Al-Razi and tacked the instances of irregular Qiraat by looking into their phenetic, morphological and semantic levels. The study reveals several findings: the research suggests that both irregular and Mutawatir Qiraah can be used as authoritative sources in all branches of linguistics. The findings also suggest that some Arabic morphological and syntactic rules are influenced by irregular Qiraah due to the fact that irregular Qiraat served to preserve Arabic grammatical rules. Moreover, the findings indicate that there is such an intimate connection between Arabic phonology and the other branches of Arabic linguistics.
\end{abstract}

Keywords: Irregular Qiraat, Syntax, Morphology, Phenetics, Semantics.

\section{Introduction}

There seems to be a consensus amongst scholars of Quranic Qiraat that one of the (Qumqam, 2007; Abdelgelil, 2020), essential requirements for accepting a particular Qiraah (i.e. Quranic 
reading or recitation) is that it must be consistent with one of the grammatical aspects of Arabic (Abdelgelil, 2020). Therefore, both types of Quranic Qiraat (irregular and Mutawatir) are seen as the right reflection for the linguistic realities for the Arabs. They are also considered as the original sources for Arabic dialects as well and investigations of their linguistic phenomena. In this paper, we will look at the instances of Qur'anic Qiraat mentioned in Al-Razi's book irregular Qiraat which contributed to Arabic phonological, morphological, syntactic and semantic aspects, It has been decided by linguists that the abnormal readings served the four levels, as will be seen in the following points, We also do not know from researchers who did such a study in the interpretation of Imam Al-Razi.

\section{Preliminaries}

Irregular Qiraat have broadly contributed to all branches of linguistics. Such linguistics branches include the phonological, morphological, syntactic and semantic levels.

The phonological aspect is concerned with the study of sounds (the places of articulation and manner of articulation). It mostly focuses on words with regards to its phonological structure and the way in which the sound impacts the morphological and syntactic structure. The morphological aspect refers to the level at which the structure of words, the words from which they derive and the words which may not be classified under inflection (i.e. the words whose structure changes based on their co-text) or Bina i.e. fixed structure.

The syntactic aspect is concerned with the study of the position of words in sentences. In other word, it is the study which identifies the relationship between words in the sentential structure.

The semantic aspect is concerned with the meaning of words, meaning relations such as synonymy, antonymy and hyponymy (Qhaddur, 2008; Abdelgelil, 2017).

Qiraat Mutawatirah: It Is The One That Conformed To The Arabic Grammar Rules And The Ottoman Script, And Its Evidence Was Correct, While Qiraat Ahad: Each Reading Agrees With The Arabic And Ottoman Calligraphy, But The Chain Of Transmission Is Incorrect (Abdelgelil, 2017).

According to Al-Syuti, both irregular and Quranic Mutawatir can be taken as authoritative sources. He states: "Each narrated Qiraah either Mutawati, Ahad or irregular can by used as a reliable source for Arabic, and scholars have unanimously agreed that irregular Qiraat is a reliable source if it does not contradict an established standard but may also remain as reliable" (Al-Syuti, 1989; Abdelgelil, 2019).

\section{Association between Irregular Qiraat and Arabic at the Syntactic Level}

Arabic syntactic rules were originated based on Quranic Qiraat (both irregular and Mutawatir Qiraat). It can be argued that Arabic grammatical rules were based on Quranic Qiraat. To demonstrate the impact of Quranic Qiraat, we will look at some examples from the Quranic interpretation of Al-Razi to see the underlying role of these Qiraat on Arabic grammar. Allah

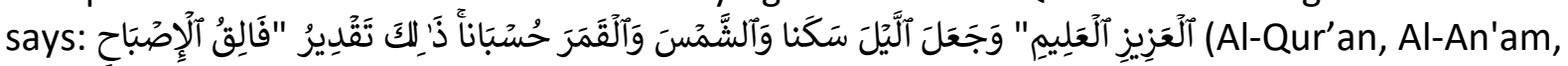
6: 96), 'wa ashamsa walkamar husbana' "And the sun and moon for calculation". In this verse, the sun and the moon were linked to the three cases of I'irab i.e. inflection (ar-raf') which indicates the doer of the action, nasb indicates the object, and Jarr indicates preposition. The nas $b$ in the verse can be identified by the implied action which is indicated by the verb made and so the verse can be interpreted as He [the Almighty Allah] has made the night, the sun, and the moon calculation. The Jarr i.e. can be identified from the conjunction of the word 'lail (i.e. night) that precedes the sun and the moon. The ar-raf' is identified because they are 
considered as a predicate of a subject i.e. implied: the sun and the moon are calculated (AlZamakhshari, 1987, 2/ 50; Al-Razi, 2000, 2/ 50; 13/ 79; Abdelgelil, 2019).

As we can see, the Qiraah of this verse can be analyzed in terms of its syntactic structure. The words 'Alshams and Al-Qamar' in the three different forms: ar-raf', al-nasb, aljar; the nasb occurred in the Qiraah Mutawatirah whereas the ar-raf' and al-Jarr occurred in the irregular Qiraat. Reading The Nasb Mutawatirah It Was Read By All Ten Imams, While Reading Jarr And Ar-Raf', Two Irregular Readings, The Jarr, Imam Abu Haywah And Imam Yazid Al-Sukuni, And The Ar-Raf' Imam Abu Muhaisin (Al- Khatib, 2002; 2/ 496; Abdelgelil, 2018).

As We Can See, The Qiraah Of This Verse Can Be Analyzed In Terms Of Its Syntactic Structure. The Words 'Alshams And Al-Qamar' In The Three Different Forms: Ar-Raf', Alnasb, Aljar; The Nasb Occurred In The Qiraah Mutawatirah Whereas The Ar-Raf' And Al-Jarr Occurred In The Irregular Qiraat.

Among The Grammar Rules Of Imam Al-Razi, It Is Related To The Qiraat, Matter, Pronoun

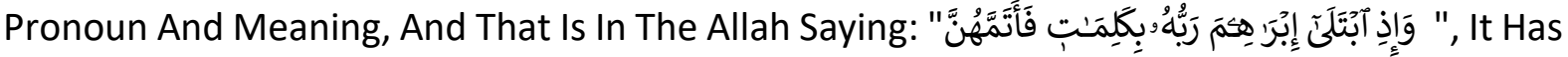
Been Shown That One Of The Rules Of Progression And Delay Of Conscience, For The Pronoun To Be Advanced In Pronunciation And Meaning, Although The Famous Among Grammarians That It Is Not Permissible (Al-Razi, 2000), 1/ 64).

Syntacticians Have Different Views Over The Principle Of Conjunction On The Nominal Subject إن Before The Nominal Predicate. Kûfiyyûn Believe That It Is Acceptable, But With A Condition. Alkisāiy Views That It Is Permissible. Al-Farrāu Opines Its Unacceptability With A Condition, Though. Al-Basriyyûn View That It Is Impermissible; This Is Evident In The World Of Allah, Allah

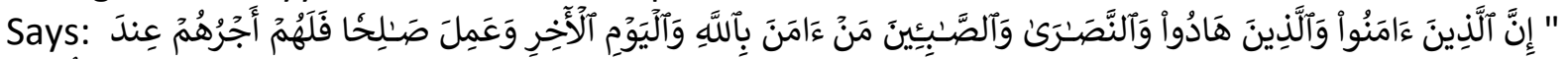

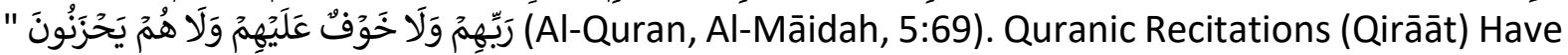
Been Revealed In Support Of Both Views (Al- Kufiyyûn And Al-Basriyyûn). However, Al-Sābiûn Is The Recurrent Recitations, While Al-Sābiīn (الصابئين)Is A Highly Irregular Recitation. The Difference Between The Two Rules Has Been Explained In Great Detail By Imam Al-Rāzi, Who Said That The Apparent Syntactic Analysis Requires Us To Read It As 'Wa Al-Sābiīn' This Is The Recitation Of ‘Ubayy Bin Ka'b, Ibn Mas' ûd And Ibn Kathīr. Syntacticians Have Stated The Rationales Behind The Famous Recitation:

First: This Is The School Of Al-Khalīl And Sībawaihi. الصَّابيُونَن Al-Sābiûn Has Raf'u From The

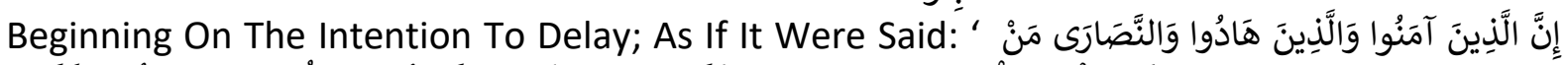

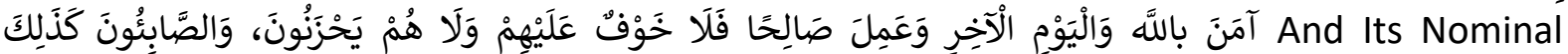
Predicate. The Benefit Of Not Using A Conjunction To Connect The Preceding Words Is That Al-Sābiīn Are The Most Highly Misguided Sect Mentioned In The Verse. This Is As If It Was Said

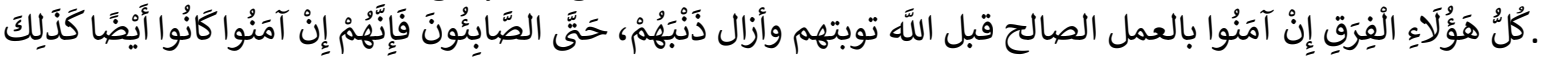
The Second View Is Attributed To Al-Farrāu. He Views That The Usage Of The Word 'Inna' Is Unconvincing Here. His Statement Is Buttressed With Some Proofs: One: The Word (إِّن ('Inna') Works For Being Remarkably Similar To The Verb. Meanwhile, It Is Well Known That The Similarity Between The Verb And The Letter Is Weak. Two, Even If It Is Operative, It Only Operates With A Noun. As For The Nominal Predicate, It Remains Marfû' For Being The Predicate Of The Subject; This Preposition Does Not Have Any Influence In Making The Predicate In A Nominative Form (Raf'u Al-Khabar), This Is The Opinion Of Kûfi School. However, Al-Rāzi Sided Both Recitations. He Explained That If The Nominal Subject Of 'Inna' Does Not Have Apparent Grammatical Analysis, What Comes After It Can Be Placed With The Accusative Case (Nasb) By Making Use Of This Letter, And Placing Raf'u By Making It Ineffective (Al-Razi, 2000, 12/ 402). 
The Syntactic Phenomena Changed According To Al-Rāzi Based On The Quranic Recitations (Al-Qirāāt Al-Qur'aniyyah), And Al-Razi Sided The Two Recitations.

In The Previous Examples, Imam Al-Rāzi Does Not Object To Any Of The Quranic Recitations. However, In The Following Example, He Objected To The Famously Recurrent Recitation, This Is Because It Is At Variance With His Syntactic Doctrine. We Disagree With This Objection In That All The Quranic Recitations (Al-Qirāāt) Are The Revelation From Allah; It Is Not Permissible To Object To Them. Besides, There Are Numbers Of Scholars Who Responded To It And Supported This Recitation. This Is Evident In The Word Of Allah, Allah Says: وَكَنَنَ لِكَ زَيَّنَ

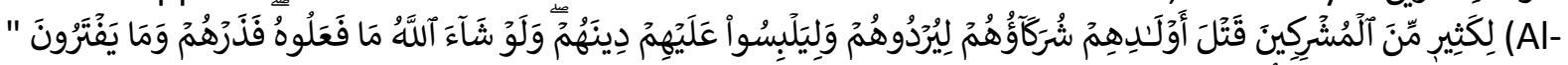

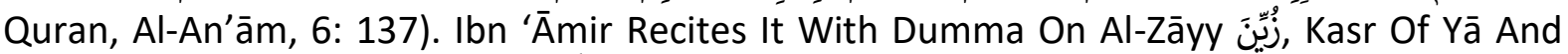

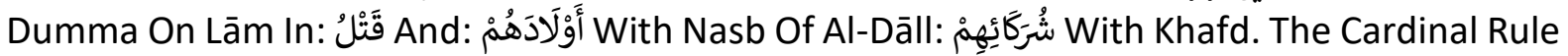
According To Syntacticians Is That It Is Not Permissible To Separate The Annexed Possessed (Al-Mudaf) And The Annexed Possessor (Al-Mudaf Ilayhi) With The Object Of A Verb (Maf'ul Bihi). Al-Razi, 2000, 13/ 159; Abdelgelil, 2018). However, The Rule Is Not Appropriate For The Existence Of This Recurrent Recitation. Hence, It Is Obvious That The Interpretation Of Quran Changes With The Change Of The Syntactic Views Of The Quranic Recitations (Al-Qirāāt AlQur'aniyyah).

This Shows That There Are Several Grammatical Rules Which Were Elicited From Irregular And Mutawatir Qiraat And That Imam Al-Razi Benefited To A Great Extent From Irregular Qiraat In His Book.

\section{The Association of Irregular Qiraat to the Arabic Language at the Morphological Level}

As regards morphology, Imam Razi resorted to irregular Qiraat to support the morphological aspects of the word, its structure, and lexical origins. In the noble verse, "وَبِمَا كُنتُمْ تَدَرُسُونَ (Qur'an, Al Imran, 3: 79). "wabima kuntum tadrusun" and because of what you have studied. Al-Razi narrated the Qiraah of Abi Haywa al-Shaza on the authority of Imam Ibn Jani and read "تُدْرِسُونَ" "Tudrisun" with dammah on the letter "Ta" skun on "dal" and kasrah on "Ra". This is probably derived from the structure "Huwa daras" (He studied) and "darras ghayrah" (He taught others) and also "qara'a" (He read) and "'Aqra'a" (He made others read). Most Arab linguists use the form "daras" (He studied) and "darras" (He taught), and from them, the "masdar" (verbal noun) "Tadris" (Teaching) is derived.

This Qiraah is related to the morphological level where it changed the structure of the word and the shape of its letters and its derivation from its linguistic root. The mutawatir Qiraah is based on the word "darasa" (He studied) while the irregular one has a different lexical derivation.

Abu Ubaidah read "تُدْرِسُون" "Tudrisun" which is derived from "udarisu" (I teach) "yudarisu" (He teaches). Altha'labi stated that its root is the four-letter verb "udarisu" (I teach) with a transitive "alif" at the beginning of the verb that influenced the meaning of the verb by making it a transitive verb that takes two objects. Therefore, the meaning will be "You teach others the book". This is supported by the irregular Qiraah of Sa'id bin Jubair: "تُحَرِّسُونَ" "Tudarisun" (You teach) which is derived from "tadris" (teaching), while the verb in the mutawatir Qiraah is transitive with a single object (Al-Tha'labi, 2000, 8/ 464- 465; Al-Razi, 2000, 8/ 272; Abdelgelil, 2018). 


\section{The Relationship of The Irregular Qiraat to The Arabic Language at The Semantic Level}

Commentators of the Noble Qur'an cite the irregular Qiraat side by side with mutawatir ones in their interpretation of the Noble Qur'an to highlight verbal connotations that may not be conveyed by the latter. Imam Al-Razi's comment on the interpretation of the noble verse, "

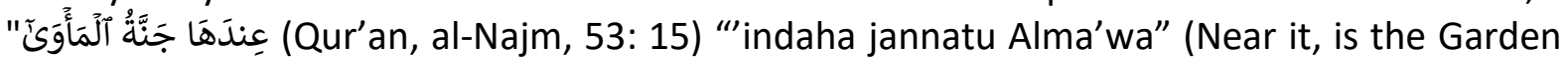
of Refuge), stresses the semantic level of the irregular Qiraah. He followed Abdullah bin Al Zubair's Qiraah in reading "janah" with a final "ha'" sound which is derived from "jannah" or "Ajanna" (approached) as in "janna al-Layal" or "ajanna al-Layal" (The night approached). Based on this Qiraah, it is possible that the pronoun in "indaha" (Near it) refers to "nazlah" (descent of Jibril from heaven), and accordingly, the meaning will be "At this descent, Muhammad came to the Garden of Refuge). However, the Imam Believes That, It Is More Probable That the Pronoun Refers To "sidrah" And This is a correct opinion. It is said that 'A' ishah did not accept that Qiraah, while others affirmed she accepted it (Al-Razi, 2000, 28/ 244; Al-Tha'labi, 2000, 9/ 144; Abdelgelil; 2019).

In the same context, several irregular Qiraat were narrated in reading "'unthuru 'la thamarehi

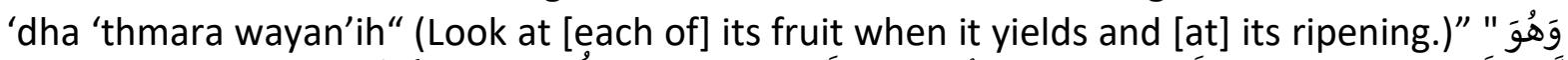

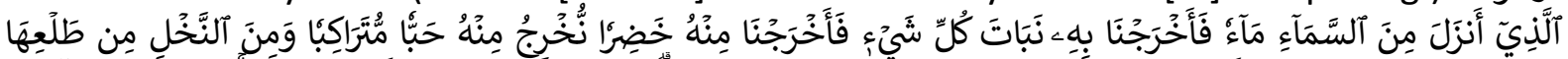

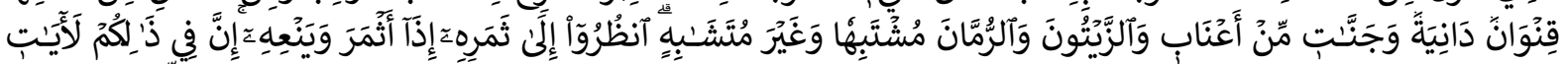

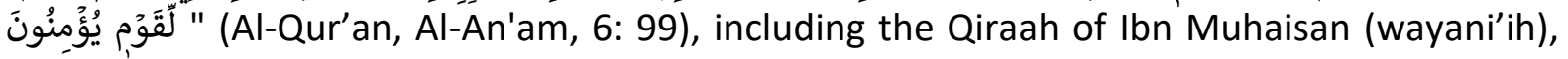
and the Qiraah of Qatada, Al-Dhahak and Ibn Muhaisen (wayun'h) with a damma vowel on the letter "Ya" which is the plural form of "yani'" meaning ripening and maturity according to the language of some of the people of Najd who say "ينعت الثمرة ينَعاً وينعاً" "yana'at althamarah yan' $n$ " to mean that the fruit ripened and became red in colour.

Therefore, the irregular Qiraat provided a new meaning that the mutawatir Qiraat miss (Ibn Atiyyah, 2002, 2/ 328; Al-Razi, 2000, 13/ 87; Abdelgelil, 2020).

\section{The Relationship of Irregular Qiraat to The Arabic Language at The Phonemic Level}

There is no doubt that phonology is one of the sciences that linguists and tajwid scholars have taken care of since it is the science concerned with the effect of the linguistic phoneme in the composition of speech, grammar and morphology. It is also the science that addresses the structure of words and sentences in a certain language (Wahbah, 1984, P. 47; Abdelgelil, et al., 2021).

The phonemic area is the most essential language aspect in building Arabic words and structures, so the phoneme is nothing but a letter dependent on a specific output, as explained by the tajwid scholars.

The phonemic forms are many. They may be related to changing the sound of a letter within a word, replacing it, or changing its vowel, whether in the structure of the word or its syntax.

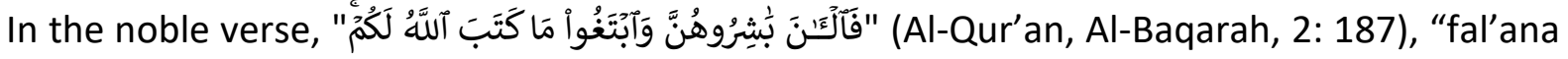
bashiruhunna wabtaghu ma kataba allah lakum." (So now you may have sexual relations with them and seek that which Allâh has ordained for you (offspring).

Imam Al-Razi said that Ibn Abas read in one of the irregular Qiraat (واتَّبِعُوا) "wattabi'u" (follow) while Al-'Amash read (وَابْغُوا) "wabghu" (seek). The Qiraah of Ibn Abbas, may Allah be pleased with him, although in line with the Uthmani script, differs in the sounds and their arrangement. The sound "Ta" comes first, then "Ba", and finally "Ain", while in the mutawatir Qiraah, comes the sound "Ba", then "Ta", then "Ghayn". In Al-A'mash's Qiraah (وَابْغوا) "wabghu" (and seek) the sound "Ta" is deleted (Al-Razi, 2000, 5/ 272; Abdelgelil, et al., 2018). 
Accordingly, all the previous examples of Imam Al-Razi's interpretation contributed to the different branches of Arabic linguistics namely morphology, grammar and semantics. They also fall under the phonemic level of the language. As mentioned above, phonology is closely associated with the other levels of Arabic.

Based on what has been mentioned above, it can be argued that the attitudes of grammarians and linguists towards irregular Qiraat were systematic and they were mostly based on the Noble Qur'an and its Qiraat. They considered them as an authoritative source. In addition, irregular Qiraat had their impacts on building morphological and linguistic rules that highlight the dialects, sayings, and poems of the Arabs as well as in establishing the grammar rules.

\section{Conclusion}

Based on this review of that linguistic Quranic topic, the following findings have been reached:

- It is permissible to take both Mutawatir and irregular Qiraat alike as an authoritative source of Arabic linguistics; Since The Irregular And Mutawatirah Recitations Are Frequently Cited By People Of Arabic Grammar And Language, It Is Permissible To Rely On Them, And The Abnormal Reading Is No Less Powerful Than The Mutawatirah Reading, This Is In Citing The Grammatical Rules, But That Differs From The Point Of Reading In Prayer And Teaching People, So That The Mutawatirah Reading Is The Only Acceptable.

- Whereas Grammarians Always Cite Anomalous Readings In Their Grammar. We Can Judge That Anomalous Readings Are Among The Pillars Of Those Grammatical Rules. And Since It Is, we can say that :Irregular Qiraat have significantly helped in the preservation of Arabic grammar.

- $\quad$ The Phonological Lesson Is The Most Original Aspect Of The Language In Building Arabic Words And Structures.

- In conclusion, I recommend future researchers to search for the same topic, but in the books of other scientists, in order to collect an integrated scientific material on this topic.

\section{Acknowledgement}

Special thanks go to the Research Management, Innovation and Commercialization Centre (CREIM), Universiti Sultan Zainal Abidin.

\section{References}

Abdelgelil, M. F. M. (2020). Grammarians' Critique of Qur'anic Qira'at. International Journal of Academic Research in Business and Social Sciences, 10(11), 1225-1231.

Abdelgelil, M. F. M. (2020). Solving the Quranic Issues with Quranic Qira'at, International Journal of Academic Research in Business and Social Sciences, 10(12), 36-42.

Abdelgelil, M. F. M., Al-Janayni, M. U., Baru, R., Hamzah, M. S., Razali, M. A. T. M., \& Ismail, F. Z. (2018). Tawjih Al-Qira'at Based on Inscription, Language, and Unusual Modes of Recitation According to Ibn Zanjalah. International Journal of Academic Research in Business and Social Sciences, 8(10), 362-370.

Abdelgelil, M. F. M., Daud, N. B., Omar, N. B., Ismail, F. Z. B., \& Wahab, A. H. B. A. (2018). Taujeeh Al-Qira'at Using Qur'an, Hadith and Poetry according to Ibn Zanjalah. International Journal of Academic Research in Business and Social Sciences, 8(10), 371379.

Abdelgelil, M. F. M., Musolin, M. H., Serour, R. O. H., Abdullah, M. S., \& Noor, M. N. M. (2018). Law and Moral Values in the Holy Quran. International Journal of Academic Research in Business and Social Sciences, 8(11), 445-451. 
Al- Khatib, A. (2002). "Mu'jam Al-Qiraat". Dimashk: Dar Saad.

Al- Khatib, A. (2002). "Mu'jam Al-Qiraat". Dimashk: Dar Saad.

Al-Quraan Al-karim.

Al-Razi, M. (2000). "Mafateih Al-Ghaib", Bairut: Dar Ihyaa Al-Turath.

Al-Razi, M. (2000). "Mafateih Al-Ghaib”, Bairut: Dar Ihyaa Al-Turath.

Al-Syuti, J. (1989). "Al-Iqtirah Fi Usul Al-Nahw", Dimashq: Dar Al-Qhalam.

Al-Syuti, J. (1989). "Al-Iqtirah Fi Usul Al-Nahw", Dimashq: Dar Al-Qhalam.

Al-Tha'labi, A. M. (2000). "Alkshf Walbyan An Tfsyr Alqran”, Bairut: Dar Ihyaa Al-Turath.

Al-Tha'labi, A. M. (2000). "Alkshf Walbyan An Tfsyr Alqran”, Bairut: Dar Ihyaa Al-Turath.

Al-Zamakhshari, M. (1987). "Al-Kashaf An Hakaik Wa Gawamid Al-Tanzil”, Bairut: Dar Al-Kitab Al- Arabi.

Al-Zamakhshari, M. (1987). "Al-Kashaf An Hakaik Wa Gawamid Al-Tanzil”, Bairut: Dar Al-Kitab Al- Arabi.

Ibn Atiyyah, M. A. (2002). "Al-Muharrar Al-Wajiz", Bairut: Dar Al-Kutub Al-Ilmiyyah.

Ibn Atiyyah, M. A. (2002). "Al-Muharrar Al-Wajiz", Bairut: Dar Al-Kutub Al-Ilmiyyah.

Qhaddur, A. (2008). "Mabadi' Al-Lisanyyat", Dimashq: Dar Al-Fikr.

Qhaddur, A. (2008). "Mabadi' Al-Lisanyyat", Dimashq: Dar Al-Fikr.

Qumqam, F. (2007). "Al-Taujih Al-Llahaji Ind Abi Ali Al-Farisi". Algeria: Kassidi Merbah University, Ma Thesis.

Qumqam, F. (2007). "Al-Taujih Al-Llahaji Ind Abi Ali Al-Farisi”. Algeria: Kassidi Merbah University, Ma Thesis.

Wahbah, M. K. (1984). "Mu'jam Mustalahat Al-Lugah Al-Arabibbah”, Bairut:Lubnan Nashirun.

Wahbah, M. K. (1984). "Mu'jam Mustalahat Al-Lugah Al-Arabibbah", Bairut:Lubnan Nashirun. 